\title{
Inflationary Pressures Continue
}

$\mathbf{E}$

XXESSIVE GROWTH of total demand for goods and services has maintained intense upward pressure on prices. The Federal budget legislation of late June, which was designed to moderate inflationary pressures, has not yet slowed appreciably the advance of total demand. Consumer spending has risen sharply in recent months, and growth of Government purchases has continued. While the tax sur charge has reduced the portion of each dollar of income available for private spending, consumers have evidently reduced their rate of saving, and have made increased use of installment credit to augment their purchasing power. In addition, monetary expansion has remained rapid, at least until recently, suggesting continued stimulus to private demand for goods and services.

\section{Demand, Production and Inventories}

The rate of increase of total spending in the third quarter showed little evidence of slowing significantly from the rapid rate of the first half of the year. Marked expansion of consumer demand, as evidenced by strong retail sales, has been the major factor in the increase. Retail sales have grown at a 15 per cent

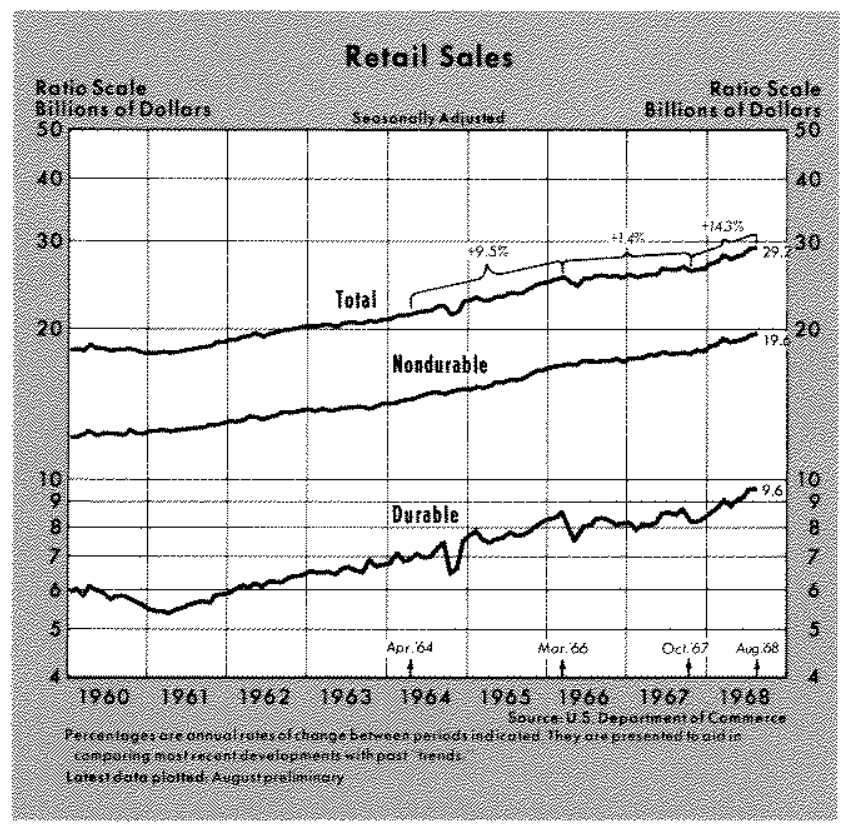

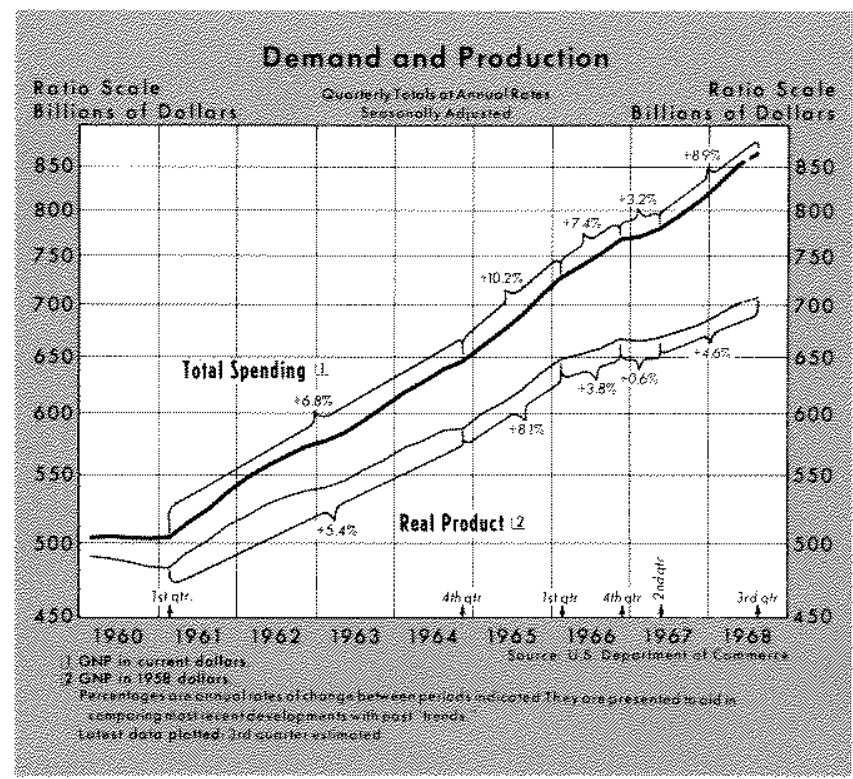

rate since late last year. Sales of new automobiles have been especially rapid in recent months.

Demand for steel fell markedly following the labor contract settlement in late July, moderating somewhat the ebullience of overall demand. Steel users had stockpiled steel earlier in the year in anticipation of shortages resulting from a potential strike. With the settlement, the backlog of steel fostered a reduction of orders, and production dropped sharply. As a result, manufacturers' inventories relative to sales rose from July to August. Production of final goods and some industrial materials other than steel has been sufficiently strong, however, to compensate in part for the decline in steel activity. Total industrial production has increased at a 5 per cent rate since about a year ago.

The rate of inventory investment for all businesses, including manufacturers, wholesalers, and retailers, increased during the four months ending in July (latest data available), but total inventories relative to sales remained near normal in late summer, and lower than in most other periods during the last two years. Business inventories increased $\$ 3,6$ billion from March to July, compared with a $\$ 2.5$ billion increase during the previous four months. The acceleration of 


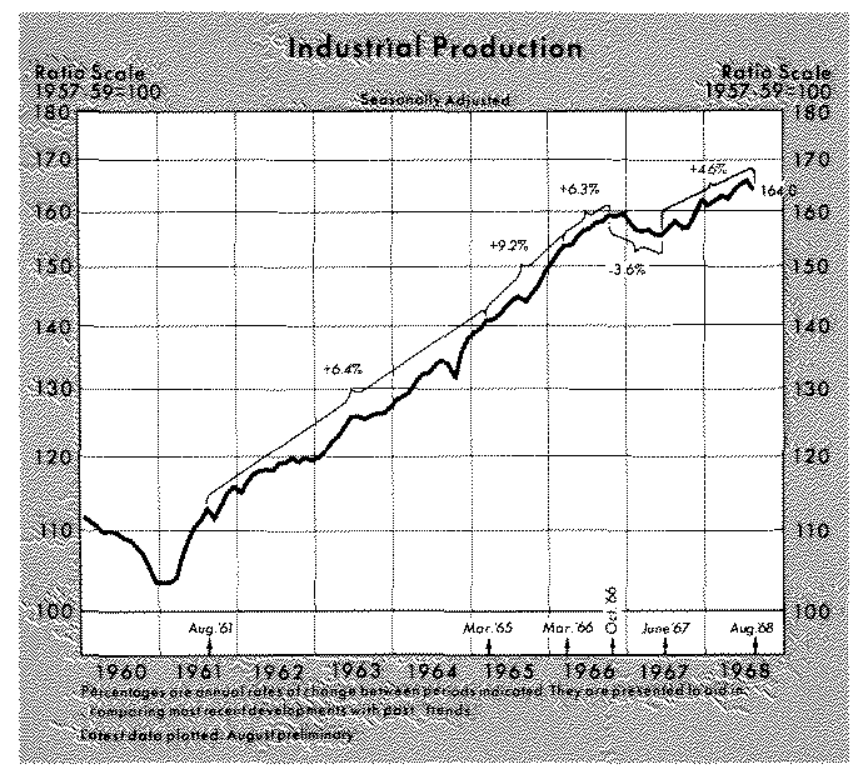

inventory investment, however, was overshadowed by the sharp advance of sales, dropping the ratio of inventories to sales to near normal.

\section{Employment and Income}

Total civilian employment has increased at a 2 per cent annual rate since the beginning of the year. Most entrants into the labor force have been able to find work, and unemployment has been relatively stable, averaging 3.6 per cent of the labor force so far this year. Among married males, unemployment has averaged 1.6 per cent.

Employment growth and wage increases have contributed to rapid increases in income. From late 1967, personal income has risen at a 10 per cent annual

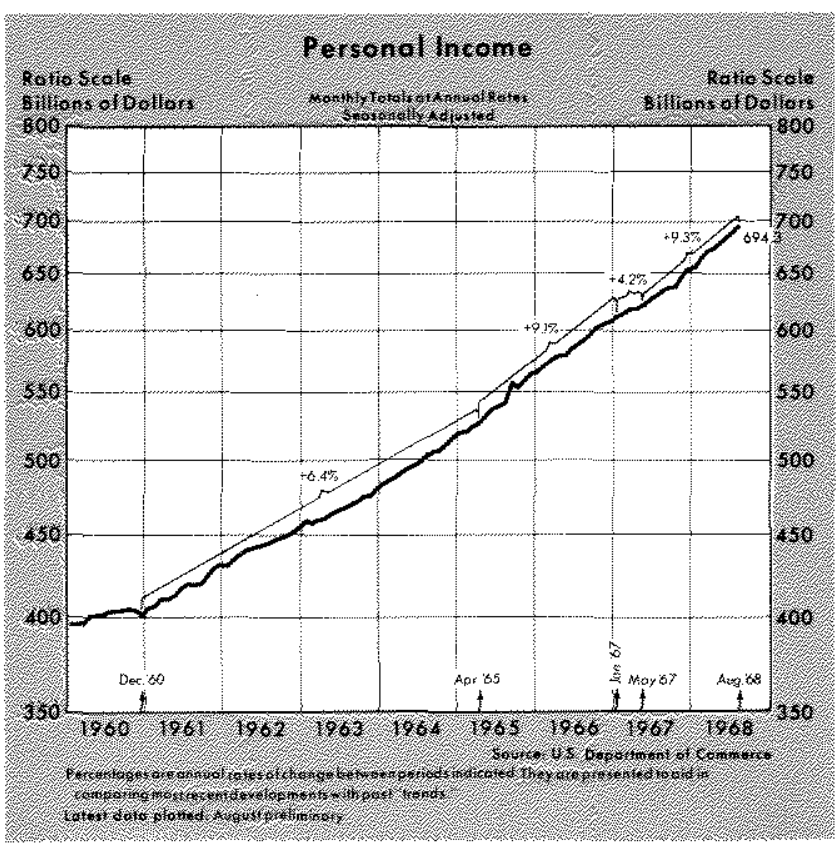

rate, compared with a 6 per cent rate of increase earlier in 1967. The strong demand for qualified workers has been reflected in greater wage increases, which have bolstered the gains in income. Average hourly earnings in manufacturing rose at a 4.2 per cent annual rate during the first eight months of this year, compared with a trend rate of 3.3 per cent from 1957 to 1967.

Although the recently enacted income tax surcharge has restrained growth of take-home pay, the tax hike has not yet dampened consumer spending. The impact of the surtax is relatively small on those with low incomes, and others have apparently counteracted the surcharge to some degree by reducing the portion of their income allocated to savings. Some of the impact has perhaps been delayed until next spring. Tax withholdings in 1968 are less than tax liabilities, and next April many individuals will receive smaller refunds or make larger tax payments.

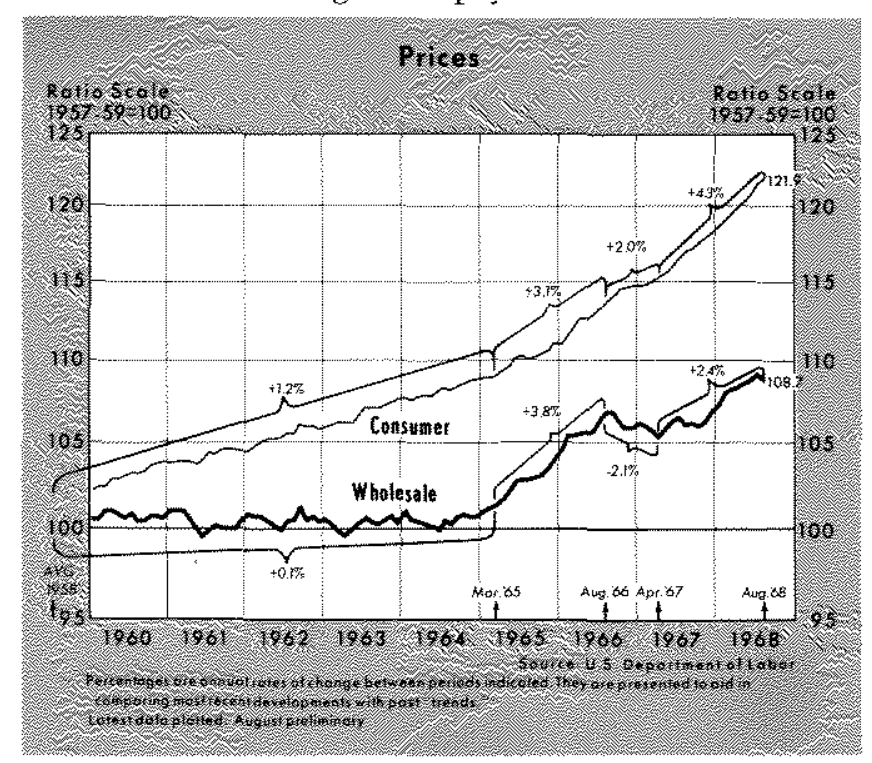

\section{Inflation}

The acceleration of prices, which began late in 1965, has continued through the third quarter. Upward pressure on prices from vigorous demand still prevails. Prices, as measured by the GNP deflator, rose at a 3 per cent annual rate from late 1965 to mid-1967 and have accelerated to over a 4 per cent rate since mid-1967. Prices rose at a 1.6 per cent rate from late 1957 to 1965.

Consumer prices have risen at a 3 per cent average annual rate during the last three years, compared with a 1.2 per cent average rate from 1958 to 1965. These prices increased 4.3 per cent during the last year, a rate of increase as great or greater 
than in 93 per cent of all consecutive twelve-month periods since January 1949.

For the twelve-month period ending in August, increases in both wholesale agricultural and industrial commodity prices resulted in a 2.5 per cent rate of increase in overall wholesale prices. This rate placed the most recent twelve-month period in the 78th percentile of all consecutive twelve-month periods since January 1949.

Recent inflation has adversely affected the position of the United States in international markets. The merchandise trade account, in which the United States has enjoyed a strong surplus over most of the period since World War II, showed a surplus of only $\$ 40$ million in the second quarter. Preliminary data have indicated a relatively small deficit in the third quarter. The decline from a surplus of $\$ 4.4$ billion in the second quarter of 1967 was caused mainly by a sharp increase in imports, as accelerating prices in this country diminished the attractiveness of domestic products relative to foreign goods. In addition, more rapid rises in income than in the nation's ability to expand production have caused consumers and businesses to direct more of their spending to foreign goods.

\section{Federal Budget Developments}

The Federal budget deficit on a high-employment basis declined to a level of about $\$ 3$ billion in the third quarter, compared with an $\$ 11$ billion deficit a year earlier and an average surplus of $\$ 6$ billion in the period from 1957 to 1967 . This change in the deficit represents a considerable move toward fiscal restraint.

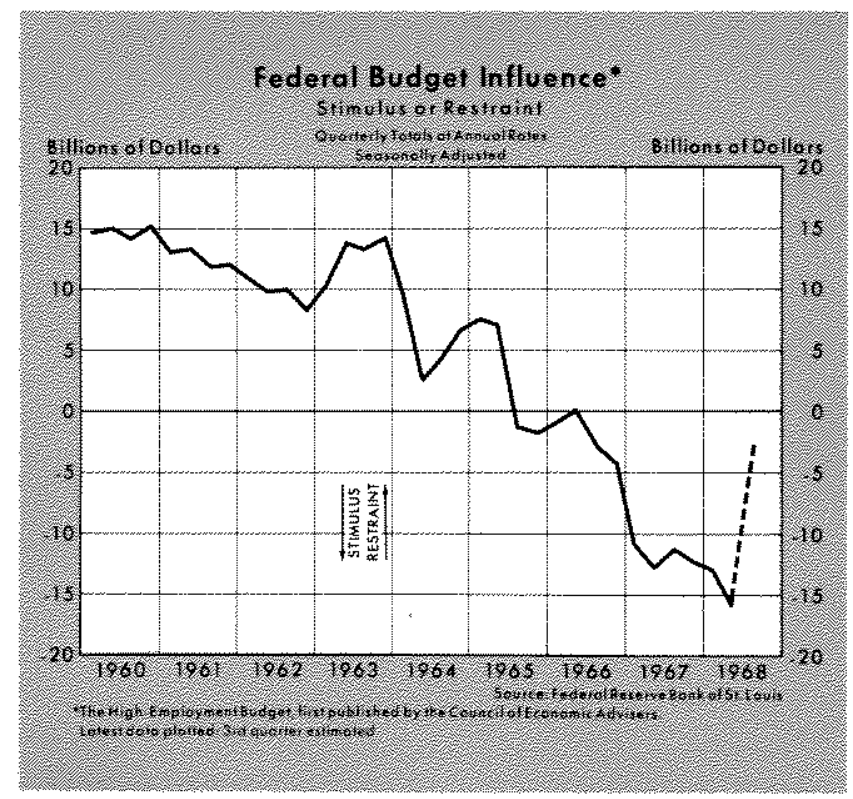

The third quarter decline in the deficit reflected in large part the fiscal legislation of June 28. Receipts on a high-employment basis rose substantially from the second to the third quarter, representing primarily the 10 per cent income tax surcharge on individuals and corporations.

The expenditure control portion of the June fiscal action had little apparent effect on Federal expenditures in the third quarter. Defense spending rose at an 8 per cent annual rate from the second to the third quarter, and was up 10 per cent from a year ago. Other Federal spending, which includes nondefense purchases of goods and services, transfer payments, grants-in-aid, and interest on the public debt, also increased at an 8 per cent annual rate from the second to the third quarter and was up 13 per cent from a year earlier. Since the momentum of Government spending is difficult to slow, the attempts to control expenditures may not be felt significantly until early 1969. However, such controls will probably have less of a restraining influence than first thought, since spending in the areas exempt from the legislated ceilings continues to rise.

Budget prospects for the fiscal year ending June 30 , 1969 were outlined in a review released September 9 by the Bureau of the Budget. Those components of Federal spending that were initially exempted from expenditure controls, namely, Vietnam expenditures, social security payments, veteran's benefits, and interest on the debt, are estimated to rise 13 per cent from fiscal 1968 to fiscal 1969, compared with an average rate of increase of 28 per cent for such programs from fiscal 1965 to fiscal 1968. The Budget Bureau's report recommends the exemption of additional programs, such as farm price support programs and public assistance, from expenditure controls. As a result of such erosion of the provisions for expenditure control, total Federal expenditures are now estimated to rise 3 per cent in fiscal 1969 from fiscal 1968.

Taking into account revised expenditure estimates, the high-employment budget is now estimated to move from a $\$ 3$ billion deficit in the third quarter to a $\$ 15$ billion surplus in the second quarter of 1969. The large shift from deficit to surplus depends upon realization of the currently planned slowing of expenditure growth, as well as the retroactive feature of the surcharge on individual income taxes, the scheduled increase in social security tax rates, and the normal growth in revenue as the economy expands. If the surtax expires on June 30, 1969 as currently scheduled, the high-employment budget would revert from the large surplus of the spring of 1969 to near balance in the third quarter of that year. 
Though the June fiscal program has been in effect for a full quarter, it has not yet registered a significant impact on consumer or business spending. Fiscal restraint may be expected to be greater in the first half of 1969 than in the last half of 1968 for several reasons: 1) Since consumers and businesses are not always quick to alter their spending patterns in response to changes in after-tax income, the full effect of the surcharge is not expected until the first half of 1969, and even then the temporary nature of the surtax may moderate its effect on private spending. 2) Large tax payments will be due early next year for that portion of tax liabilities not withheld in 1968. 3) Social security tax rates are scheduled to increase on January 1, 1969, withdrawing an estimated $\$ 3$ billion annually from private income.

The success of the fiscal program in slowing growth of total demand may depend in considerable part on the monetary expansion that accompanies the budget

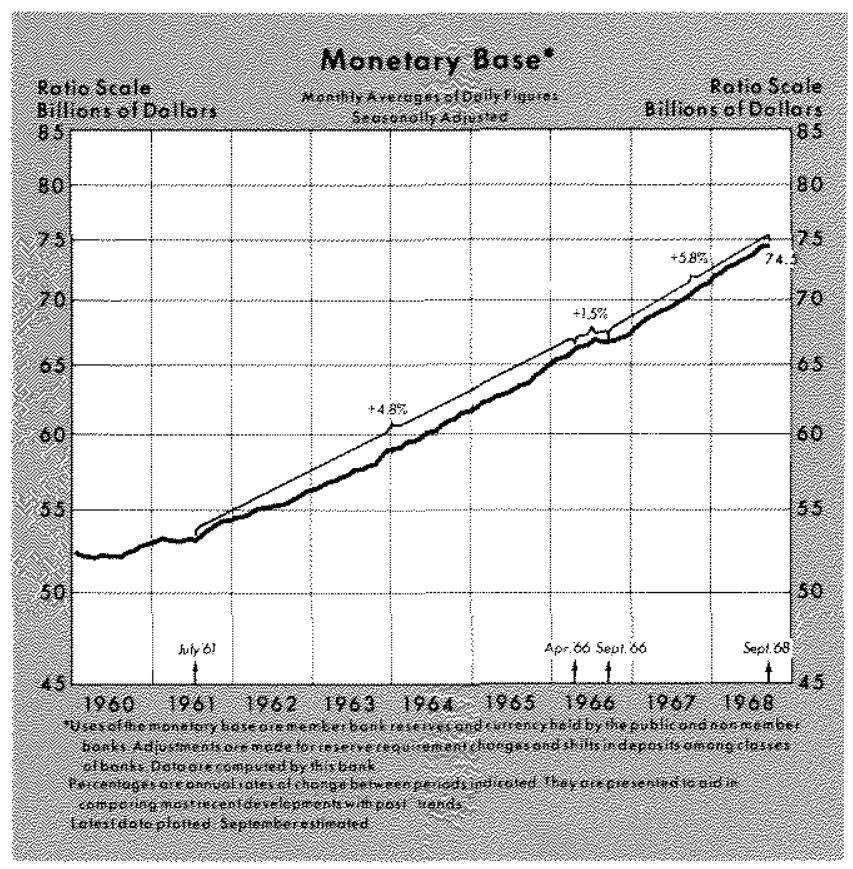

shift during the second half of 1968 and the first half of 1969. Treasury borrowing in the second half of 1968, although somewhat less than a year earlier and less than it would have been without the fiscal package, is still large compared with most past periods. As Federal demands for credit are reduced, there is less pressure to expand monetary aggregates in order to moderate upward movements in interest rates.

\section{Monetary Developments}

Rapid monetary expansion, which began early in 1967 and continued at least into July of this year, contributed to excessive demands and inflationary

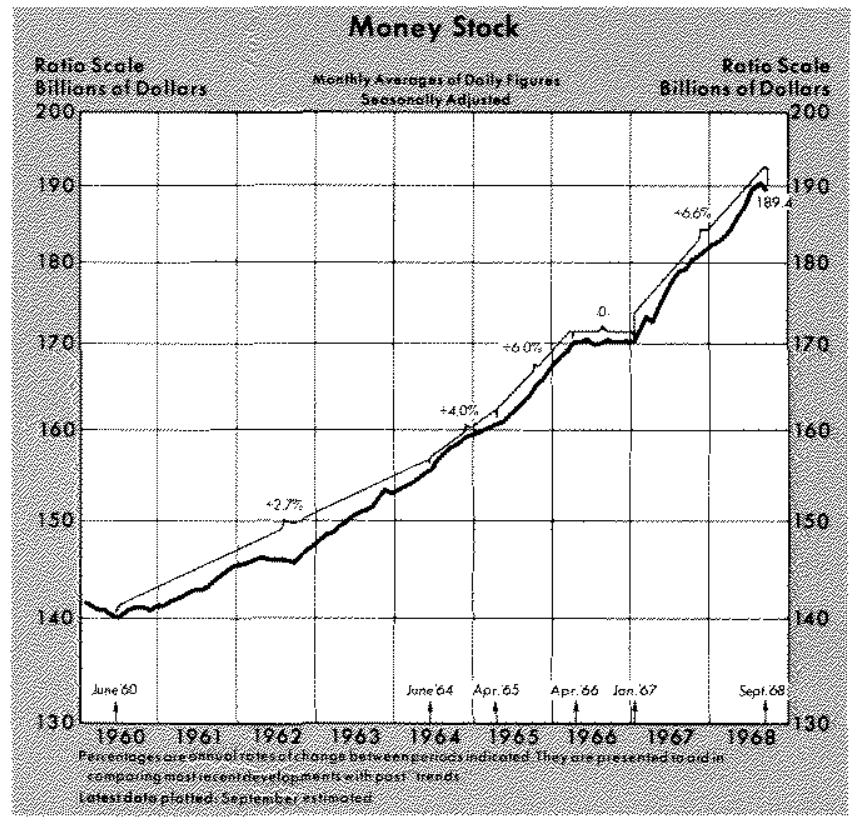

pressures. The monetary base has increased at a 4.9 per cent annual rate in the six months since March, compared with a 3 per cent average rate of increase from 1957 to 1966.

The money stock, consisting of private demand deposits and currency, has increased at a 7 per cent annual rate since March and 6 per cent in the last year. While the money stock changed little from mid-July to late September, so short a period may not be of sufficient length to assure a restraining effect. During the decade from 1957 to 1967 the money stock rose at an average rate of 2.6 per cent.

Bank credit has expanded at a 17.1 per cent amnual rate since early June, about twice the average rate

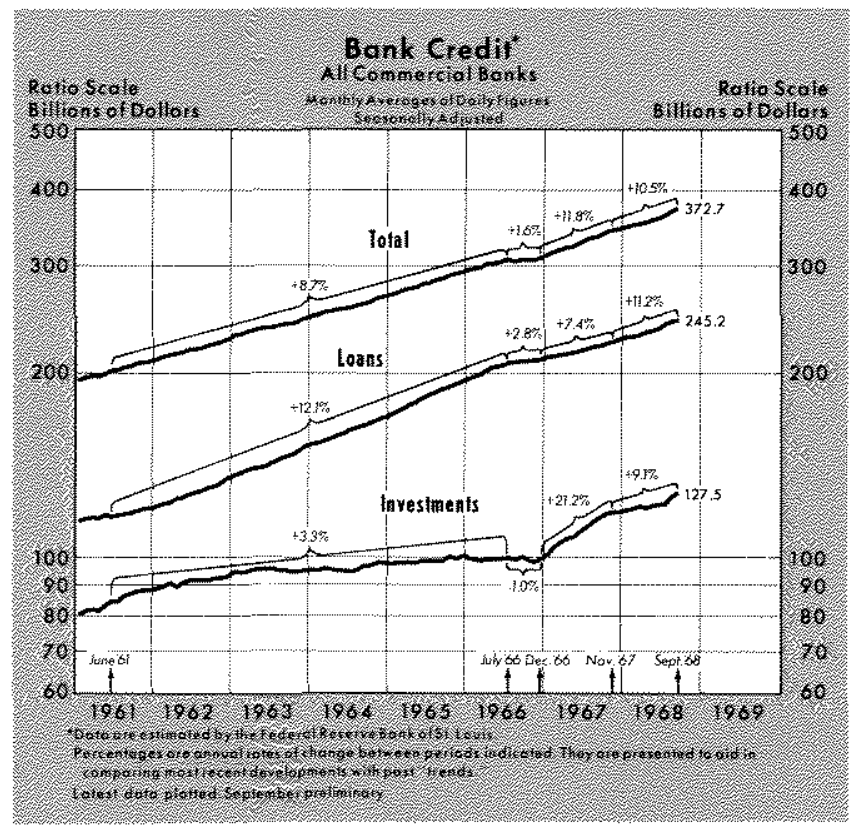




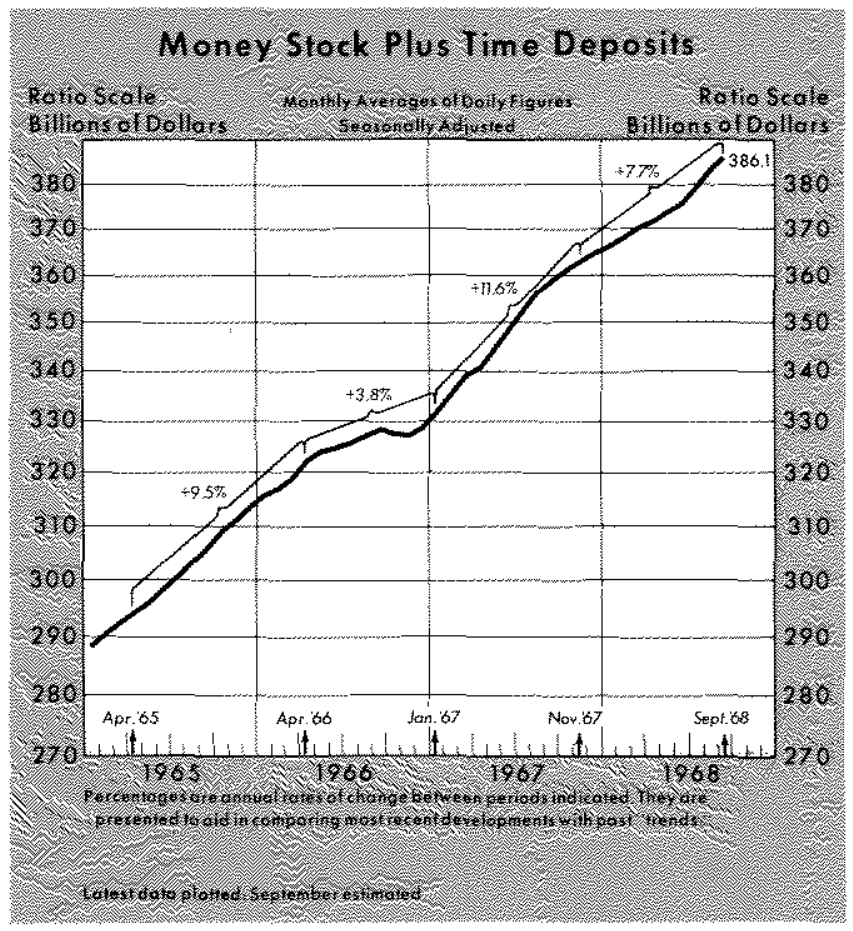

from 1957 to 1966 . This recent rapid increase reflects in large part the success of banks in attracting time deposits since mid-year following the decline of market interest rates relative to Regulation $Q$ ceilings. The acceleration of bank credit therefore reflects a rerouting of lendable funds and not a sharp expansion of total credit. Similarly, acceleration of money plus time deposits since mid-year has resulted from the bank reintermediation and does not evidence acceleration of monetary stimulus.

The relatively rapid pace of recent monetary expansion can be measured by comparison with various recent time periods. The growth rates of seven selected monetary variables for four periods of varying length ending in September are presented in Table I. For example, the money supply increased

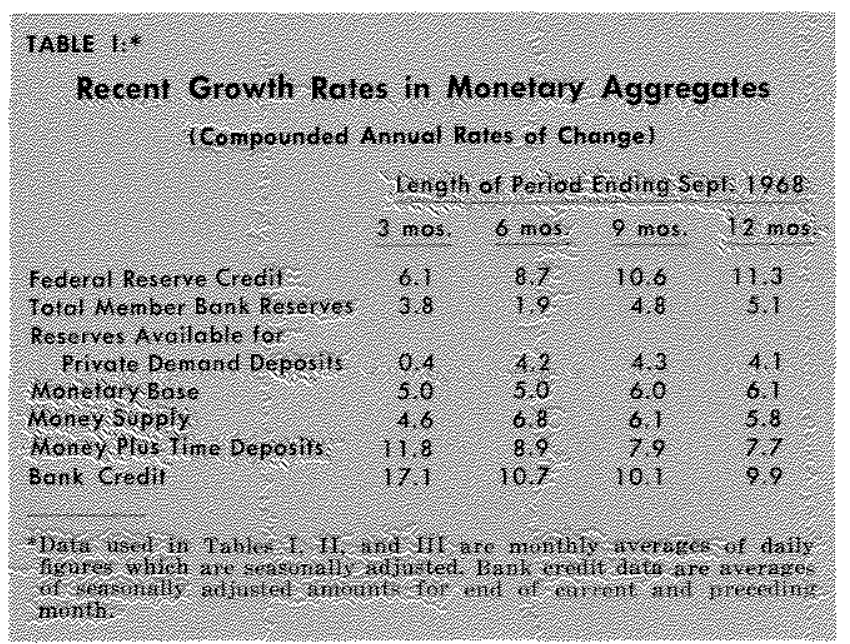

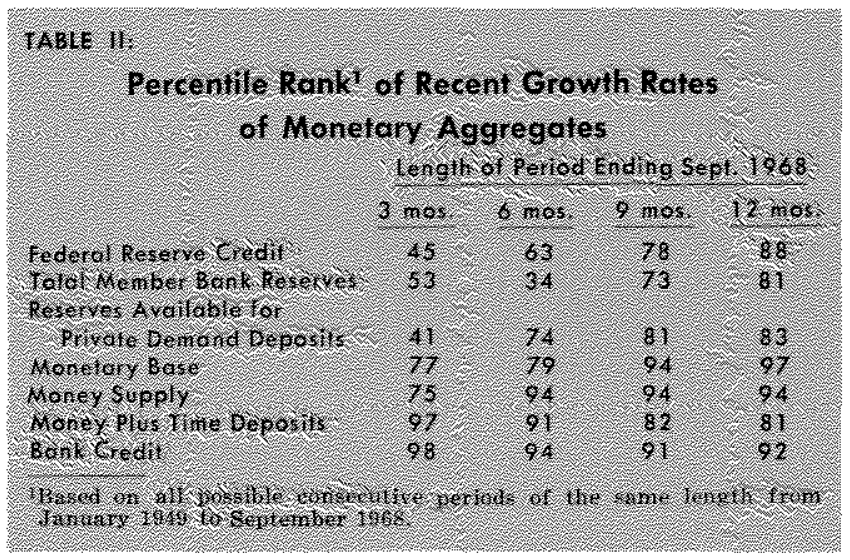

at a 6.8 per cont annual rate during the six-month period from March to September and at a 4.6 per cent rate from June.

Historical Comparisons - The relative speed of monetary expansion may be judged by comparing the most recent three, six, nine, and twelve-month periods with all consecutive periods of similar length since January 1949 (Table II). The 6.8 per cent rate of increase of the money supply over the latest six-month period has been as fast or faster than in 94 per cent of all other consecutive six-month periods since January 1949. The most recent three-month period rate of growth of the money supply ranked in the 75th percentile among all possible consecutive three-month periods since January 1949.

The growth of money has been relatively rapid whether examined over a three, six, nine, or twelvemonth period, bat the deceleration since mid-July is reflected in the somewhat lower percentile ranking of money growth during the latest three-month period. The growth rate of a monetary variable becomes increasingly significant the longer it is maintained. While the rate of growth of bank credit from June to September was in the 98th percentile, it reflected primarily the effects of market interest rates falling below Regulation $Q$ ceilings and not a sharp expansion of total credit.

Factors Affecting Money-Many factors affect short-run fluctuations in the money stock. Table III presents a summary of the influence of these factors on the rate of change of money in recent periods. The actions of the factors other than the Federal Reserve are determined by interest rates, wealth, income and other economic variables. The rate of change of money is equal to the sum of the influences of the various factors. For example, from June to September Government demand deposits at member banks increased and, in the absence of change in any cther factor, would have caused money to decrease at a 2.8 per cent annual rate. In the absence of the 


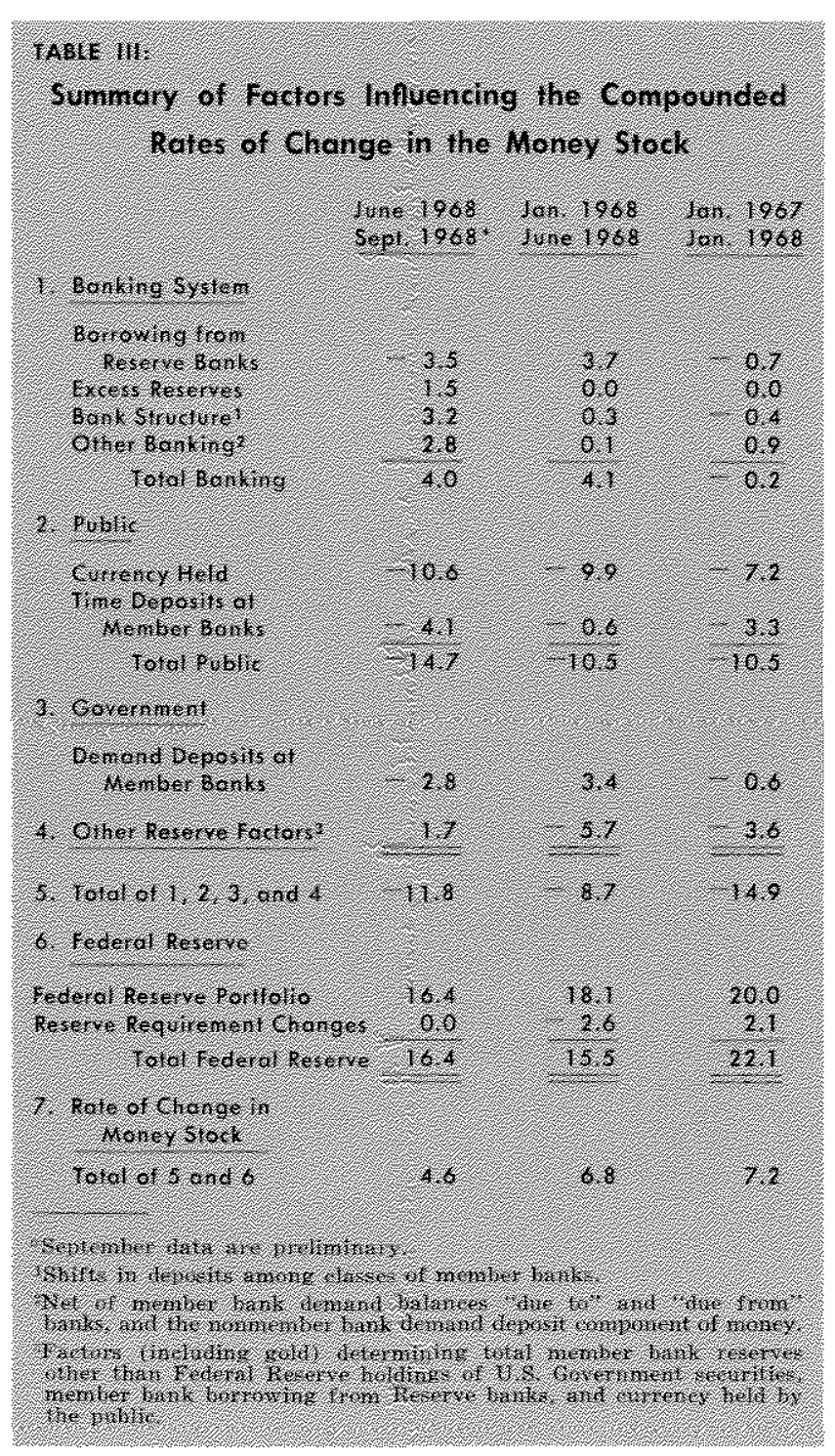

increase in Government demand deposits, the money stock would have grown at a 7.4 per cent annual rate instead of a 4.6 per cent rate. The influence of most factors on the rate of change of money tends to be small or temporary, but even when the influence is large or sustained it can be offset by Federal Reserve actions.

Federal Reserve open market operations, as Table III illustrates, have been the major factor contributing to the rapid growth of money since January 1967. From January 1967 to January of this year, net purchases of securities by the Federal Reserve, taken alone, would have increased the money stock by 20 per cent. Over the three-month period ending in September, open market actions alone would have increased money at a 16.4 per cent anmual rate.

Interest Rates - After declining in June and July, interest rates in general have shown little net change, and remain well above their averages for the last two years. The yield on three-month Treasury bills fell from a peak of 5.82 per cent in May to a 5.00 to 5.35 per cent range in early August, and has since remained at about this level. Yields on longer term securities have shown a similar pattern.

The decline in rates in June and July rellected, in part, the influence of anticipation and enactment of the fiscal restraint program on expectations regarding total demand and demand for loan funds. Anticipation of moderated economic activity and reduction of the Federal deficit, with consequent easing of demands for credit, probably contributed to the decline in rates. With this outlook, investors were willing to absorb larger amounts of securities, expecting the price to rise in the future. The effect was to bring about the decline in rates which was expected. The decline in rates may also have been influenced by very rapid monetary expansion before mid-year. The continued strong demand for goods and services, which has been contrary to expectations, probably weakened some investor optimism and may explain partly the stability of rates since early August.

The fiscal program will sharply reduce the Federal deficit during this fiscal year. The Treasury will borrow about $\$ 14$ billion over the last six months of 1968 , compared with $\$ 19$ billion in the last six months of 1967. The demand for funds by the Treasury will probably decline throughout the fiscal year and provide a progressive easing of pressure on rates from the Federal sector.

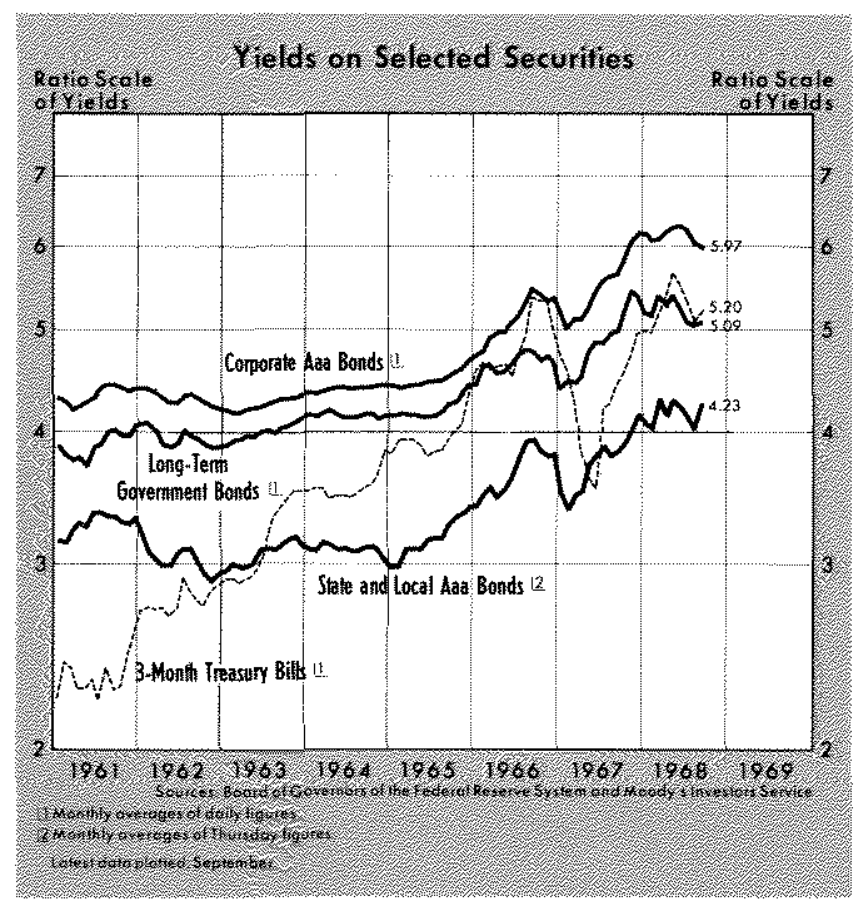




\section{Federal Reserve Regulation Amended}

Federal Reserve Regulation D, concerning reserves of member banks, was amended effective September 12. The major features of the amendment include: 1) establishment of a one-week reserve period for nonreserve city banks as well as for reserve city banks, 2) calculation of reserve requirements based on deposits two weeks earlier, 3) use of vault cash of two weeks earlier in meeting reserve requirements, and 4) a provision that either an excess or deficiency in reserve balances averaging up to 2 per cent of required reserves may be carried forward to the next reserve week.

The new regulation puts all banks on a standard reporting schedule and the lag feature makes it possible for member banks to meet their reserve requirements more precisely, probably reducing the average level of excess reserves. Since required reserves are established prior to the reserve period and are met by either supplied or borrowed reserves, the impact of monetary actions designed to reduce rates of growth of bank reserves may be delayed by increased borrowing from Federal Reserve Banks. Previously, open market operations may have been offset for a time by changes in member bank borrowing from Reserve Banks, but these operations also tended to cause banks to make asset adjustments which immediately changed demand deposits and required reserves.

\section{Summary}

Total demand for goods and services continued to be excessive through September, and upward pressure on prices persisted, probably reflecting in part the lagged effect of the rapid monetary expansion which occurred prior to mid-year. The rate of monetary expansion has been no greater since mid-year than in the preceding 18 months and may have been significantly lower. The rate of growth of bank credit and of money plus time deposits has reflected to some extent the shift of market interest rates on substitute assets relative to the ceiling rates permitted under Regulation Q.

Consumer spending has not yet been restrained materially by the tax program. It is too soon to know how consumers and businesses will finally react to higher taxes, but recent sales strength, large liquid asset holdings, and credit availability indicate that the restrictive impact of the June fiscal action may be reduced from original expectations. 